\title{
Isotopic Survey of Lake Davis and the Local Groundwater
}

\author{
Author \\ Maureen Ridley \\ Contributing Authors \\ Jean Moran \\ Michael Singleton
}

August 2007

Lawrence Livermore National Laboratory

\section{Environmental Protection Department Environmental Restoration Division}


This document was prepared as an account of work sponsored by an agency of the United States Government. Neither the United States Government nor the University of California nor any of their employees, makes any warranty, express or implied, or assumes any legal liability or responsibility for the accuracy, completeness, or usefulness of any information, apparatus, product, or process disclosed, or represents that its use would not infringe privately owned rights. Reference herein to any specific commercial product, process, or service by trade name, trademark, manufacturer, or otherwise, does not necessarily constitute or imply its endorsement, recommendation, or favoring by the United States Government or the University of California. The views and opinions of authors expressed herein do not necessarily state or reflect those of the United States Government or the University of California, and shall not be used for advertising or product endorsement purposes.

This work was performed under the auspices of the U.S. Department of Energy by University of California, Lawrence Livermore National Laboratory under Contract W-7405-Eng-48. 


\section{Table of Contents}

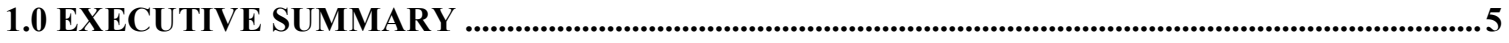

2.0 INTRODUCTION ........................................................................................................................................6

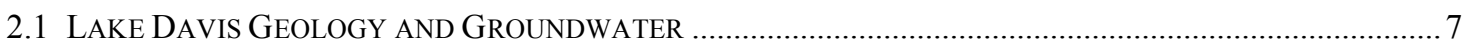

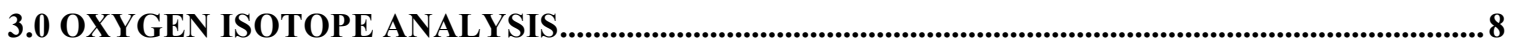

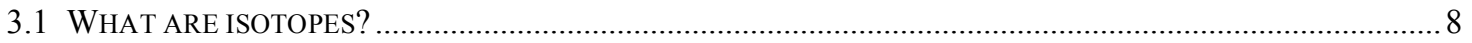

3.2 HOW ARE ISOTOPES USED TO TRACE THE SOURCE OF WELL WATER? ............................................... 9

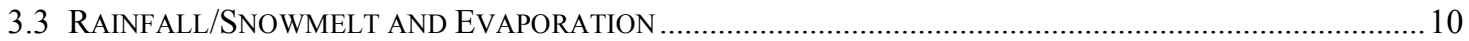

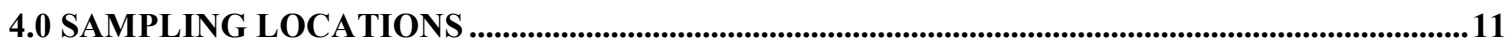

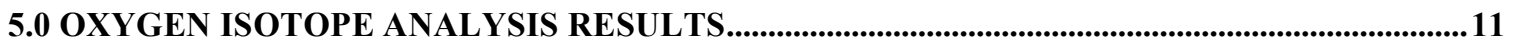

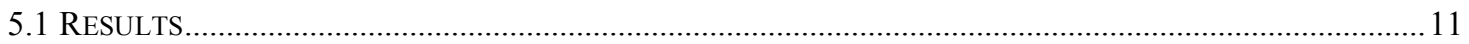

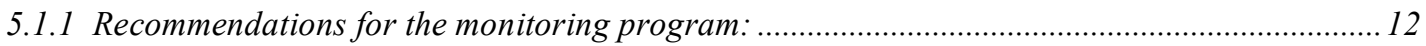

6.0 FUTURE WORK .............................................................................................................................................13

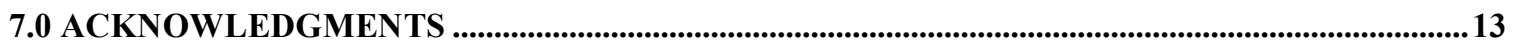

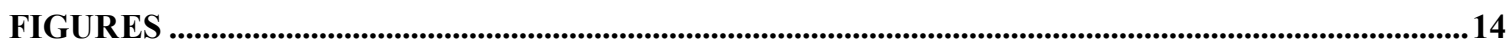

TABLES …….......................................................................................................................................22

APPENDICES .....................................................................................................................................29

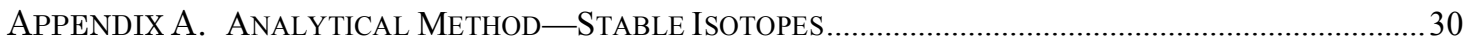

APPENDIX B. OXYGEN ISOTOPE SAMPLING PROCEDURE....................................................................... 31 


\section{List of Figures}

Figure 1. Lake Davis Area Map

Figure 2. Estimated Groundwater Elevation Contours in the Vicinity of Lake Davis Figure 3. Map of Lake Davis showing the tributaries

Figure 4. Oxygen Isotope Sampling Locations

Figure 5. Oxygen Isotope Results

Figure 6. Deuterium Isotope Results

Figure 7. Oxygen and Deuterium Isotope Results

\section{List of Tables}

Table 1. Groundwater Oxygen and Deuterium Results

Table 2. Surface Water Oxygen and Deuterium Results

Table 3. Groundwater Wells Analyzed for Oxygen Isotopes

\section{List of Appendices}

Appendix A: Analytical Method - Stable Isotopes

Appendix B: Isotope Sampling Procedure 


\subsection{Executive Summary}

In September 2007, California Fish and Game (CAFG) plans to eradicate the northern pike from Lake Davis. As a result of the eradication treatment, local residents have concerns that the treatment might impact the local groundwater quality. To address the concerns of the residents, Lawrence Livermore National Laboratory (LLNL) recommended measuring the naturally occurring stable oxygen isotopes in local groundwater wells, Lake Davis, and the Lake Davis tributaries. The purpose of these measurements is to determine if the source of the local groundwater is either rain/snowmelt, Lake Davis/Big Grizzly Creek water or a mixture of Lake Davis/Big Grizzly Creek and rain/snowmelt.

As a result of natural evaporation, Lake Davis and the water flowing into Big Grizzly Creek are naturally enriched in ${ }^{18}$ oxygen $\left({ }^{18} \mathrm{O}\right)$, and if a source of a well's water is Lake Davis or Big Grizzly Creek, the well water will contain a much higher concentration of ${ }^{18} \mathrm{O}$. This survey will allow for the identification of groundwater wells whose water source is Lake Davis or Big Grizzly Creek. The results of this survey will be useful in the development of a water-quality monitoring program for the upcoming Lake Davis treatment.

LLNL analyzed 167 groundwater wells (Table 1), 12 monthly samples from Lake Davis (Table 2), 3 samples from Lake Davis tributaries (Table 2), and 8 Big Grizzly Creek samples (Table 2). Of the 167 groundwater wells sampled and analyzed, only 2 wells contained a significant component of evaporated water, with an isotope composition similar to Lake Davis water. The other 163 groundwater wells have isotope compositions which indicate that their water source is rain/snowmelt. 


\subsection{Introduction}

Lake Davis is a man-made reservoir located in the Plumas National Forest, Plumas County, California. The California Department of Water Resources (CDWR) operates Lake Davis for recreation and to supply domestic water to the city of Portola and the Grizzly Lake Resort Improvement District. The locations of Lake Davis and Portola are shown in Figure 1.

In 1997, rotenone was applied to Lake Davis in an effort to eradicate the Northern Pike. The Northern Pike are a nonnative invasive fish species illegally introduced to California. Pike can seriously impact aquatic ecosystems by preying heavily on other fish species. Rotenone is a naturally occurring rotenoid obtained from roots of tropical plants. At Lake Davis, two products were used, liquid formulated Nusyn-Noxfish Fish Toxicant, and the powdered Pro-Noxfish Dust Fish Toxicant. Both products contained chemical substances beside rotenone. Volatile organic compounds (VOCs), including trichloroethylene (TCE), xylene isomers, and naphthalene, and semi-volatile organic methylnaphthalene isomers, are used to assist in the dispersal of rotenone in aqueous systems. The pesticide synergist piperonyl butoxide (PBO) was also included in the formulation to enhance rotenone fish kill efficacy.

To address the concerns of the local citizens as to the effect the pike eradication treatment might have on the surrounding groundwater system, a groundwater-monitoring program was initiated. Groundwater sampling was to be conducted over a ten-year period. Since 1999, the Plumas County Environmental Health Department has been monitoring the groundwater adjacent to Lake Davis and below the dam along Big Grizzly Creek. Currently, Plumas County is nine years into the ten-year program. The monitoring program tests for volatile organic compounds, semi-VOCs, and PBO.

Lawrence Livermore National Laboratory (LLNL) was contacted in October of 2005 by the Plumas County Environmental Health Department, requesting assistance in reviewing and assessing the Lake Davis monitoring program. The review included providing assessments of the analytical data generated by the monitoring program, analytical laboratory performance, the current sampling procedure, and the effectiveness of the current monitoring network, and providing recommendations for future refinements to the monitoring program.

The two main findings of the LLNL groundwater quality monitoring program assessment (Ridley, 2006) were:

1) The 1997 treatment had no impact on the local groundwater quality.

2) The groundwater hydrology needed further investigation. The 
water levels of most of the groundwater wells around Lake Davis are above the water level of Lake Davis, and most the groundwater wells in the Big Grizzly corridor are above the water level of Big Grizzly Creek. For wells with water levels above Lake Davis or Big Grizzly Creek the source of their water is most likely rain and snowmelt. As a result of the hydrological gradient around Lake Davis and Big Grizzly corridor, the local groundwater feeds into Lake Davis and Big Grizzly Creek. However, the local groundwater monitoring wells are installed in fractured rock, and these fractures may allow for some water from the lake or creek to enter into a groundwater well. As a result of this uncertainty, LLNL recommended oxygen isotope testing to determine the source (Lake Davis, Big Grizzly Creek, and/or rain and snowmelt) of the groundwater wells.

In April of 2007, Plumas County Environmental Health Department contacted LLNL and requested assistance in performing the oxygen isotope survey. This report presents the results of the oxygen isotope survey of Lake Davis and the local groundwater wells.

\subsection{Lake Davis Geology and Groundwater}

The geology of the Lake Davis area is generally a fractured bedrock system covered by ancient lake deposit sediments. These sediments may act as a liner to Lake Davis. The area also contains a number of faults. A fracture is a break in the rock mass, whereas a fault is a break in a rock mass along which movement has occurred. Generally, the local groundwater surrounding Lake Davis area flows toward, and eventually drains into, Lake Davis, or Big Grizzly Creek. The local groundwater levels and movement/flow are greatly influenced by the area's fractured bedrock and faults. Figure 2 provides a snapshot of the groundwater movement for June 2007. Groundwater flow can be affected by seasonal changes and this groundwater contour map (Figure 2) may show changes near the lake and creek. The flow direction is an estimate based on groundwater elevation measurements. The degree to which groundwater flow can be influenced by fractures and faults is uncertain, and this uncertainty is the reason for performing oxygen isotope analysis.

A detailed description of the structural geology of the Lake Davis area is presented in Leland R. Gardner and Associates Report (Gardner, 1999). 


\subsection{Oxygen Isotope Analysis}

\subsection{What are isotopes?}

All atoms are made up of electrons (-), protons $(+)$, and neutrons. All atoms of an element have the same number of protons in the nucleus, but for many atoms, such as oxygen $(\mathrm{O})$, there can be different number of neutrons. Atoms with different number of neutrons are called isotopes. Oxygen has 3 naturally occurring stable (non-radioactive) isotopes, ${ }^{18} \mathrm{O},{ }^{17} \mathrm{O}$, and ${ }^{16} \mathrm{O}$.

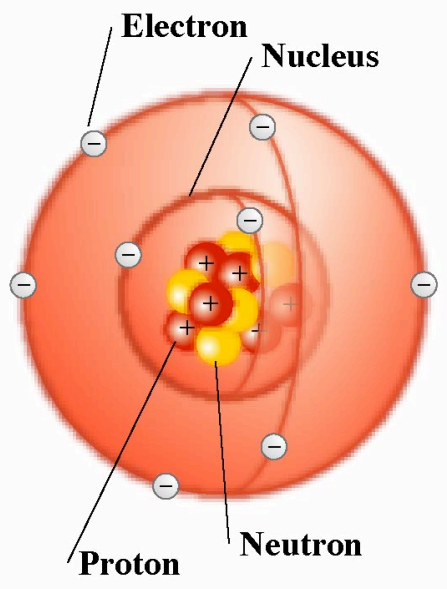

Water molecules contain two atoms of hydrogen $(\mathrm{H})$ and one atom of oxygen $(\mathrm{O})$.

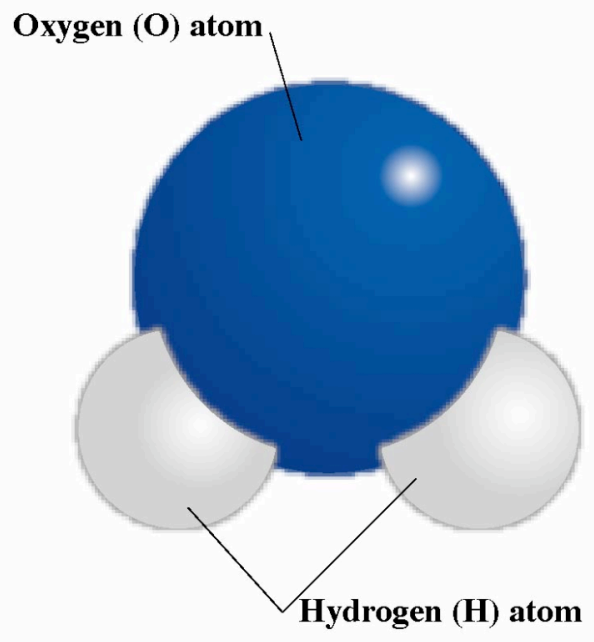

A typical water molecule is comprised of two atoms of hydrogen having one proton each (called protium) and one atom of ${ }^{16} \mathrm{O}$ ( 8 neutrons). Less commonly, a water molecule 
may contain atoms of hydrogen with one proton and one neutron (called deuterium) and/or an atom of ${ }^{18} \mathrm{O}$ (10 neutrons).

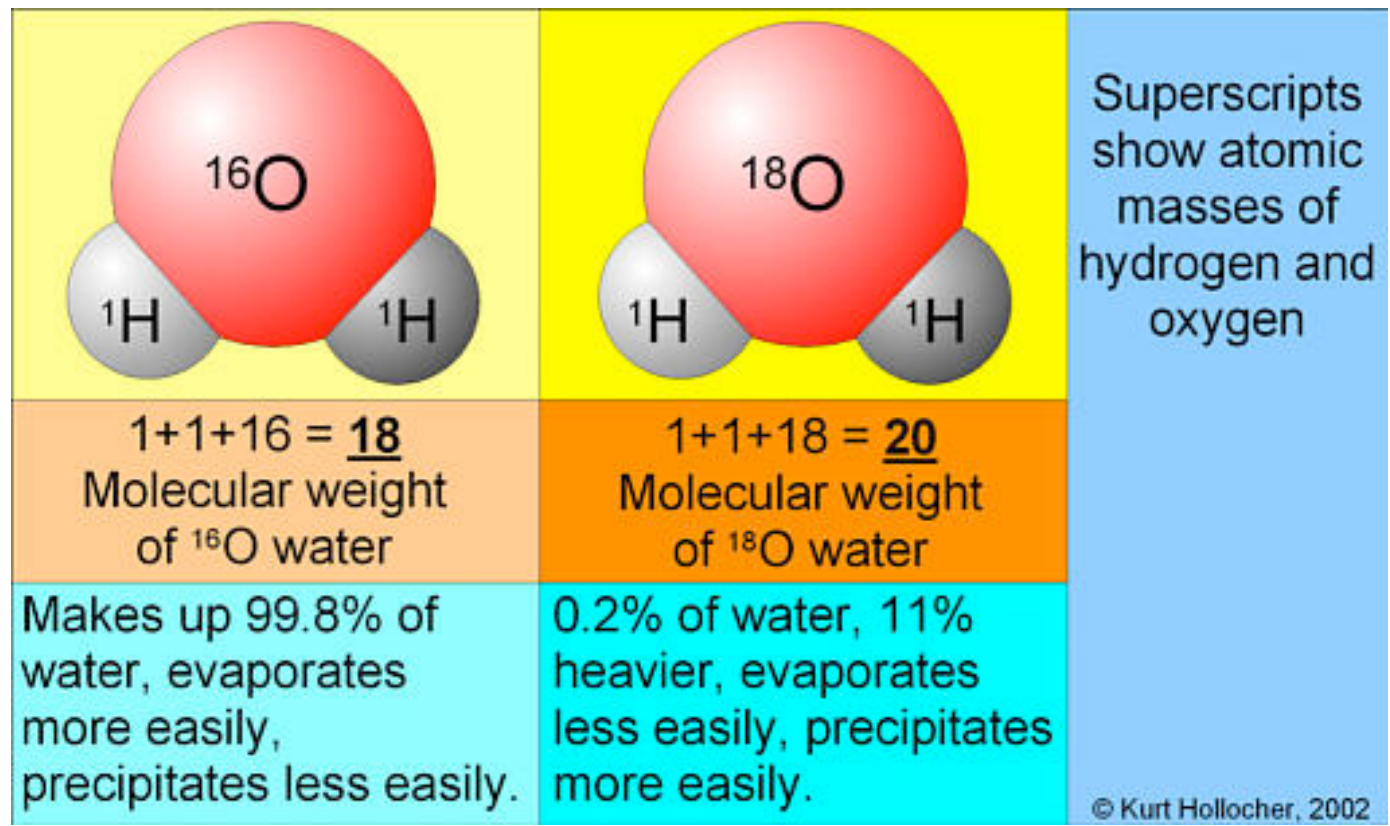

\subsection{How are isotopes used to trace the source of well water?} A water molecule containing ${ }^{16} \mathrm{O}$ is lighter, and evaporates more easily than a water molecule containing ${ }^{18} \mathrm{O}$. As a result of natural evaporation, lakes in dry climates contain higher levels ${ }^{18} \mathrm{O}$ than water that has infiltrated in to the groundwater from rain/snow. The amount of evaporation from the lake is determined by the balance of inflow and outflow water. Lakes such as Lake Davis where evaporation is significant have a higher level of ${ }^{18} \mathrm{O}$ give lake water a very distinct "isotopic signature". 


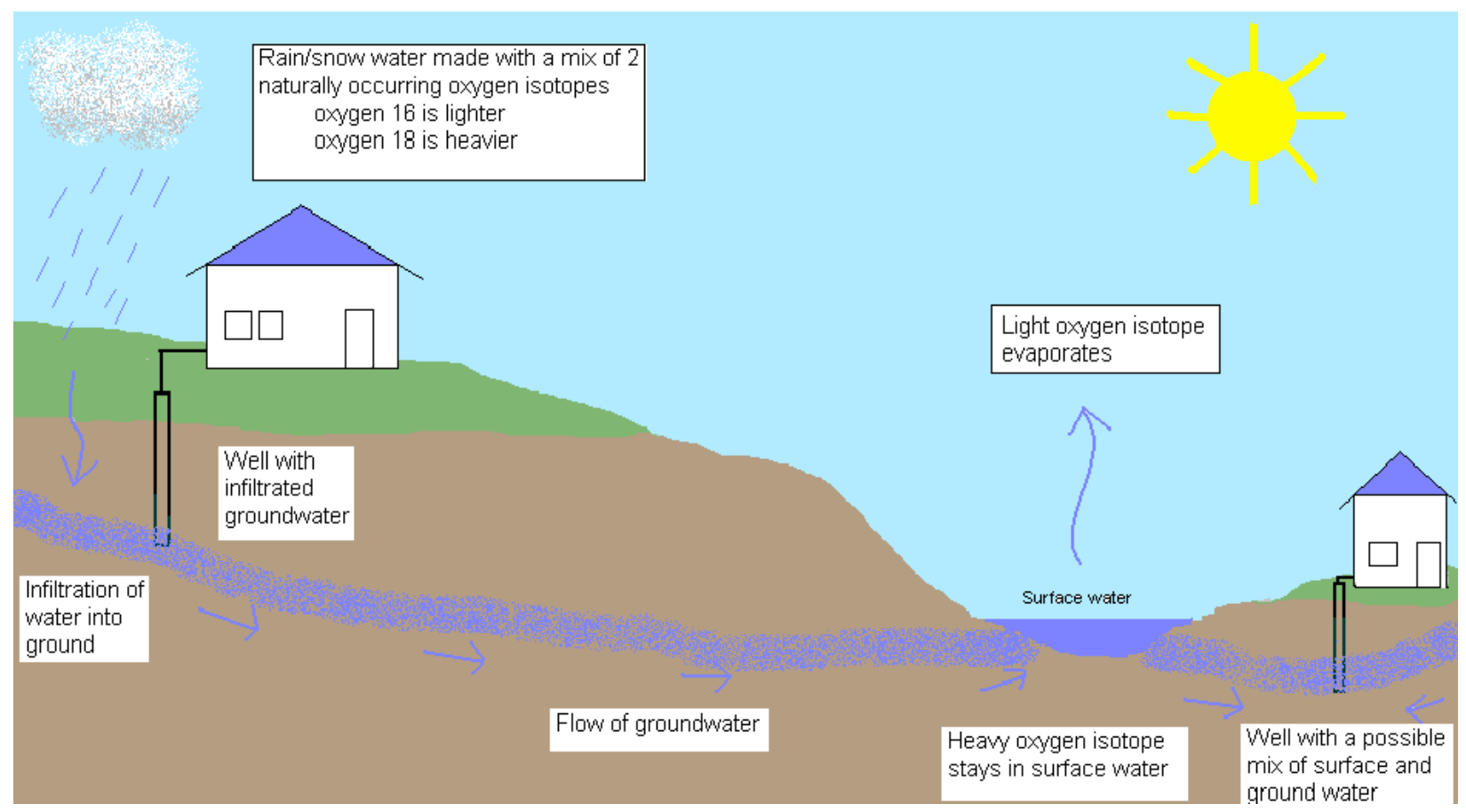

By measuring ratio of ${ }^{18} \mathrm{O}$ to ${ }^{16} \mathrm{O}$ in a groundwater well (the "isotope signature"), a scientist can tell how much of the well water comes from a lake or streams, and how much comes from the infiltrated snow/rain. The ratio of ${ }^{18} \mathrm{O}$ to ${ }^{16} \mathrm{O}$ is compared to standard mean ocean water (SMOW) using the following equations:

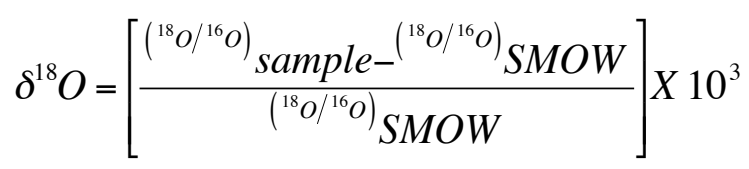

A detailed description of the oxygen isotope analytical method is presented in Appendix A.

\subsection{Rain/Snowmelt and Evaporation}

In addition to measuring the oxygen isotopes, the two stable isotopes of hydrogen were also measured. These results are useful in further distinguishing the difference between normal rain/snowmelt and Lake Davis water, and validating the oxygen isotope results. Deuterium $\left({ }^{2} \mathrm{H}\right.$ or $\left.\mathrm{D}\right)$ is a heavier isotope of hydrogen compared to protium $\left({ }^{1} \mathrm{H}\right)$, and evaporates at a slower rate than the ${ }^{1} \mathrm{H}$. The $\delta^{2} \mathrm{H}$ and $\delta^{18} \mathrm{O}$ values for rainfall or precipitation worldwide behave predictably, falling along the global meteoric water line (GMWL) as defined by Craig (1961b); the relationship between $\delta^{18} \mathrm{O}$ and $\delta^{2} \mathrm{H}$ in meteoric waters can be expressed as follows:

$$
\delta^{2} \mathrm{H}=8 \delta^{18} \mathrm{O}+10 \%
$$


By plotting the Lake Davis water and local groundwater $\delta^{2} \mathrm{H}$ versus $\delta^{18} \mathrm{O}$ results, the shift in isotope ratios due to evaporation of surface water is clearly observed, and the amount of Lake Davis water in a mixed groundwater sample can be calculated.

\subsection{Sampling Locations}

The oxygen isotope testing was available to any well owner around Lake Davis and in the Big Grizzly Creek Corridor. In addition, isotope samples were automatically taken for well owners already enrolled in the existing Plumas County Environmental Health (PCEH)'s well-testing program.

Samples were taken from the following locations:

- Lake Davis: Monthly samples were taken from Lake Davis to determine the amount of variation in Lake Davis throughout the year.

- Tributaries to Lake Davis: Big Grizzly Creek, Freeman Creek, and Cow Creek (Figure 3).

- Big Grizzly Creek: Samples were taken along Big Grizzly Creek Approximately 0.5 miles, 1 mile, and 2 miles below the Dam, and above the Ice Pond, at the Ice Pond, below the Ice Pond, and just before Highway 70.

- Local Groundwater wells: 167 local wells were sampled (Table 3 and Figure 4).

\subsection{Oxygen Isotope Analysis Results}

\subsection{Results}

The Lake Davis 2007 isotopic survey began by obtaining monthly water samples from Lake Davis to establish an average ${ }^{18} \mathrm{O}$ concentration. In addition, samples were taken along Big Grizzly Creek to ensure the water in Big Grizzly Creek is predominantly Lake Davis water. The Lake Davis water and the Big Grizzly Creek water have approximately the same strong oxygen isotope signature (Figure 7).

Next, the groundwater samples were taken. The oxygen isotope results (Figure 5) show one groundwater well (Well\#1 - 025-100-029) containing a significant component of water with an isotope signature consistent with Lake Davis water. Another well (025$350-025)$ is different enough from the rest of the groundwater results to suggest that some mixing may be occurring in this groundwater well. These wells are located several miles down Big Grizzly Creek and contain the Lake Davis water from Big Grizzly Creek. The water flowing down Big Grizzly Creek is Lake Davis water.

The deuterium isotope results (Figure 6) similarly show only one groundwater well (Well\#1 - 025-100-029) containing a significant component of Lake Davis water.

In Figure 7, most groundwater samples fall in a narrow range along the Global Meteoric Water Line (GMWL), which is consistent with recharge from high elevation precipitation/snowmelt that has not been affected by lake evaporation. Samples from the outlet of Lake Davis, samples collected above and below the thermocline, and along Big Grizzly Creek, fall in a tight cluster that is shifted off of the GMWL. The sample results 
from the inlets of Grizzly Creek, Freeman Creek, and Jenkins Creek are similar to the Lake Davis samples. This relation among the surface water samples is consistent with evaporation of water that had a similar initial isotopic composition to the average groundwater samples. Groundwater that contains recharge from Lake Davis will fall along the line with lower slope, or "Surface Water Trend" (Figure 7). Sample "025-100029 Well\#1" is the only clear example of groundwater that contains a significant proportion of Lake Davis water. Sample "025-350-025" potentially may contain a small percentage of Lake Davis water.

\subsubsection{Recommendations for the Monitoring Program}

The isotopic results demonstrate that the source water of almost all of the groundwater wells around Lake Davis and adjacent to Big Grizzly Creek is rainwater/snowmelt. These results are further re-enforced by the PCEH groundwater quality monitoring program, which has detected no chemicals associated with the first Lake Davis treatment from 1997. These findings are consistent with the conclusions of the LLNL "Review and Assessment of Plumas County's Groundwater Quality Monitoring at Lake Davis" report (Ridley, 2006).

In 2003, using the same isotope techniques described here, a groundwater well (128-010-048) showed the presence (less than 30\%) of Lake Davis water. However, during 2007 isotopic survey no Lake Davis water was detected in this well. The most probable explanation for this recent non-detection of Lake Davis water is dilution by rain/snowmelt. This well is installed in a very shallow aquifer significantly above the water level of the Big Grizzly Creek, located in an adjacent ravine approximately 0.25 mile from Big Grizzly Creek. The bottom of this well is above the water level of Big Grizzly Creek, and therefore obtains none of its water from Big Grizzly Creek. The initial 26 feet of this well is a sandy soil material, and the cement well seal only goes down to a depth of 21 feet. Since this well seal does not continue down past the sandy soil material to granite, this allows surface runoff/snowmelt to significantly impact this well. This is an unusual situation for this area. Most of the wells in the area only have just a few feet of topsoil material, and then enter into decomposed granite or fractured granite. This well (128-010-048) has over 26 feet of a sandy topsoil material, and doesn't enter into granite until 32 feet. The shallow emplacement of the well also makes it more likely to be affected by seasonal variations, including seasonal changes in streamflow and groundwater levels. In reviewing the well logs for the PCEH monitoring program, a 20-foot well seal, required by the California Water Well Standards (California Department of Water Resources - Bulletin 74-90), is normally more than adequate to protect most of the wells from surface influences. However, taking into account the installation of the well, and the proximity of the well to the Dam, it would be useful to continue monitoring this well. Another well (128-010-37) located in the vicinity of this well (128-010-048), further down Big Grizzly Creek has a cement seal that goes down to granite. This well is heavily pumped and drawn down below the level of Big Grizzly Creek. However, well (128-010-37) showed no Lake Davis water, therefore it appears only the area directly around the Dam may be impacted by Lake Davis water.

Based on the oxygen isotope and deuterium results, LLNL recommends monitoring the following wells: 
1. 025-100-029 well \#1

2. $025-350-025$

3. $128-010-048$

Monitoring the wells (025-100-029 (Well\#1) and 025-350-025) along Big Grizzly Creek may not be necessary. If, as planned after the upcoming 2007 treatment, the Lake Davis water is not released from the dam until there are no detections of the treatment chemicals, then there should be no treatment chemicals to monitor for in wells along Big Grizzly Creek.

In addition, it maybe useful to examine the current groundwater well elevation data for potential reverse gradients, or where the groundwater well elevation is below the lake or creek water level.

\subsection{Future Work}

LLNL will complete the oxygen isotope survey by the end of September 2007. In addition, the contract has been extended to allow for some consultation on topics related to the monitoring program.

\subsection{Acknowledgments}

Many people participated in the Lake Davis oxygen isotope survey, and all deserve to be acknowledged. This evaluation could not have happened without the help of Jerry Sipe and David Cline of Plumas County Environmental Health, and Debbie Spangler of Department of Water Resources (DWR).

In addition, the support of the management of LLNL's Environmental Restoration Division, which provides the infrastructure to conduct such work, is greatly appreciated. 


\section{Figures}




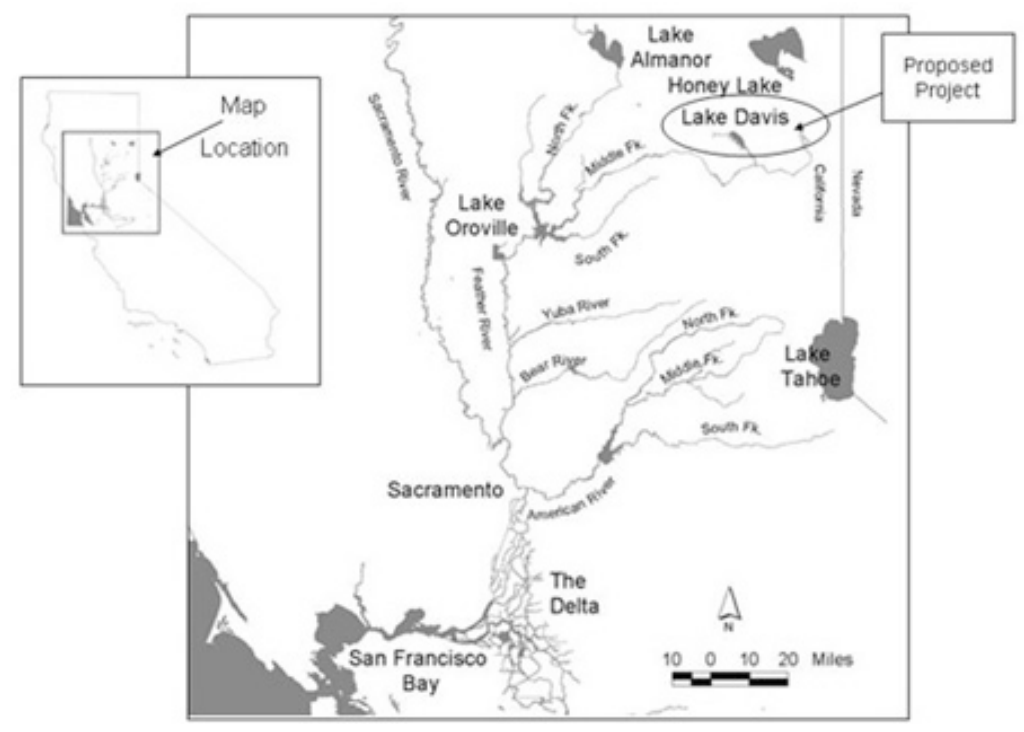

Figure 1. Lake Davis Map 


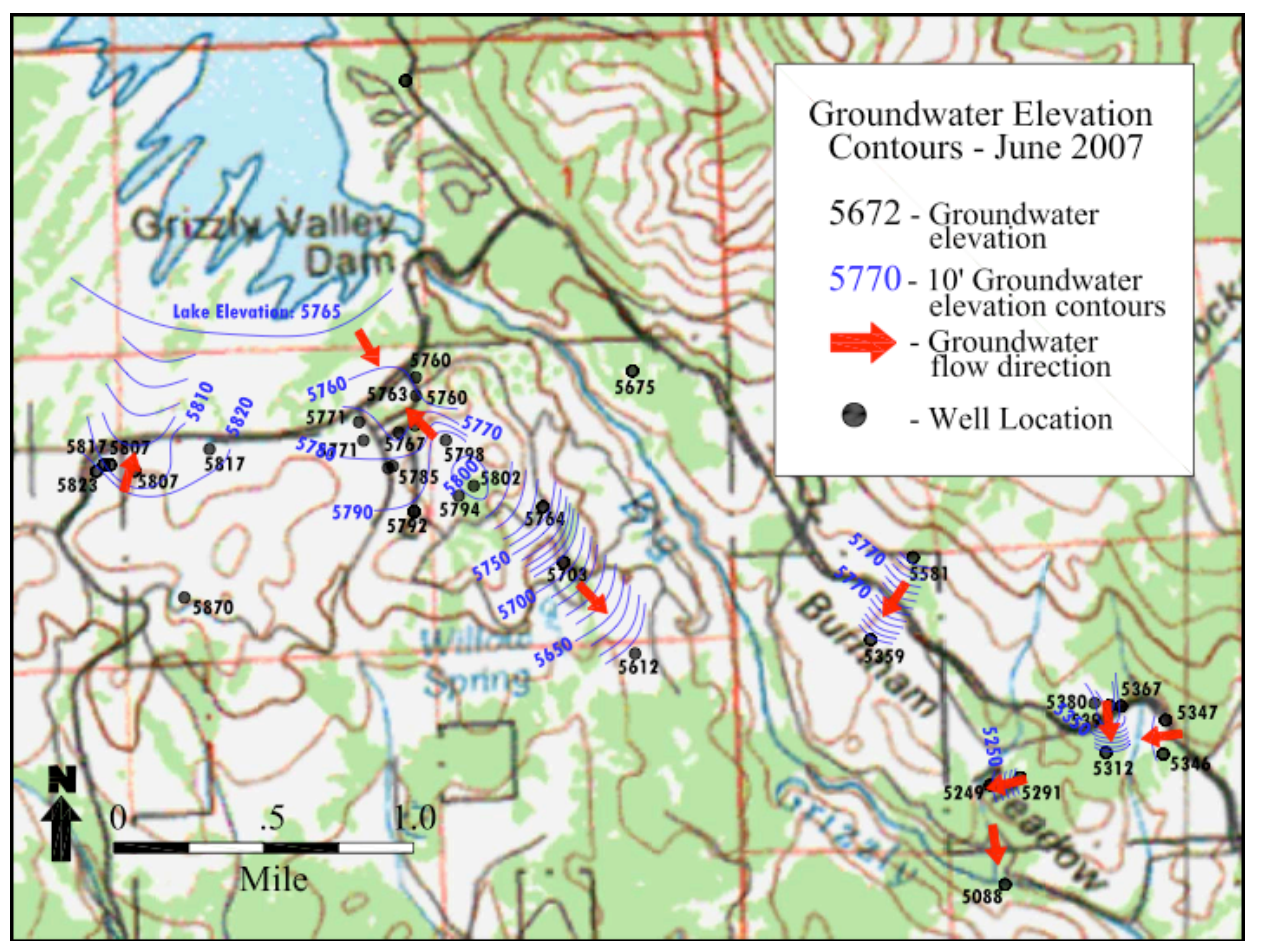

Figure 2. Estimated Groundwater Elevation Contours in the Vicinity of Lake Davis and Big Grizzly Creek 


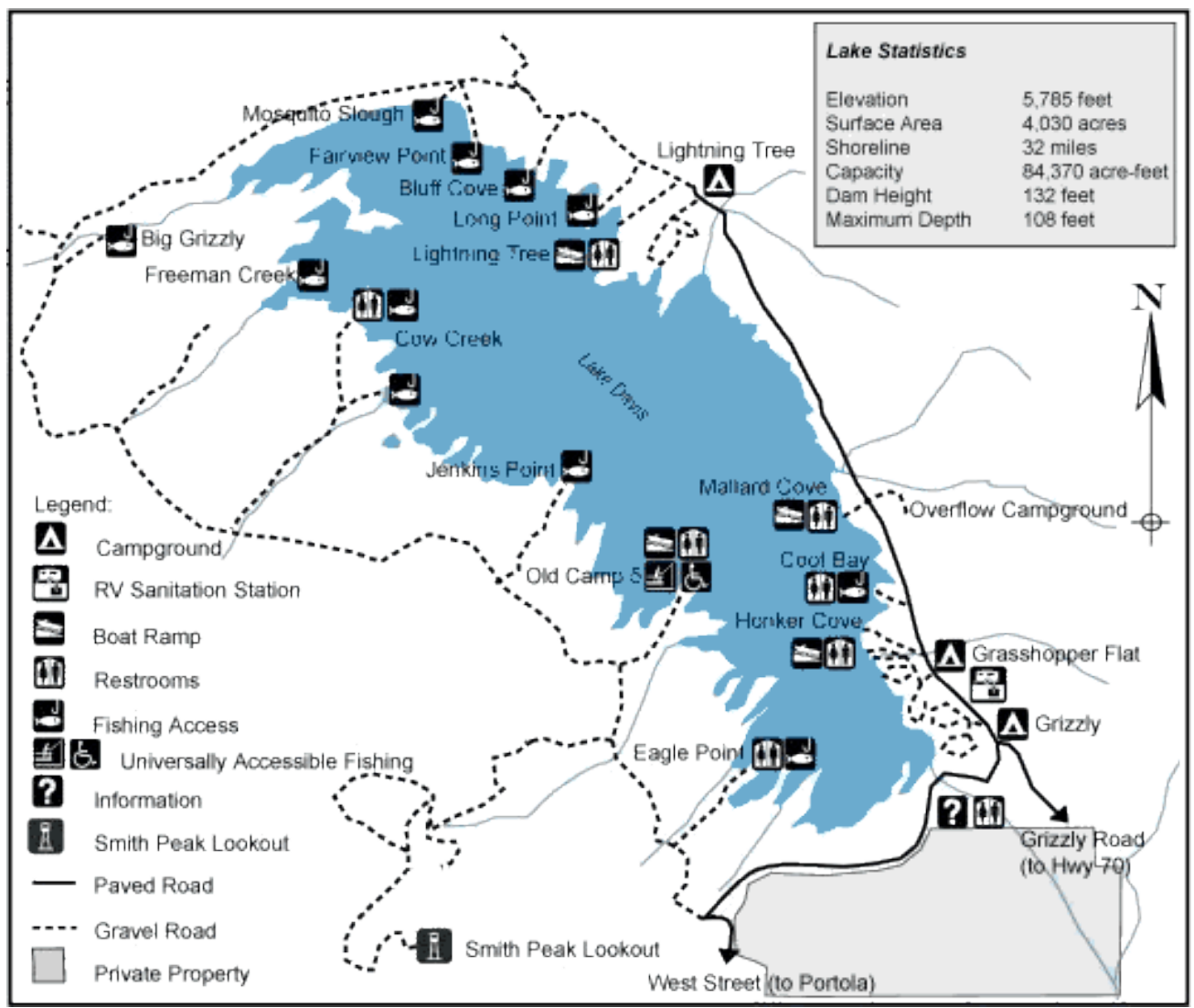

Figure 3. Map of Lake Davis showing the tributaries 


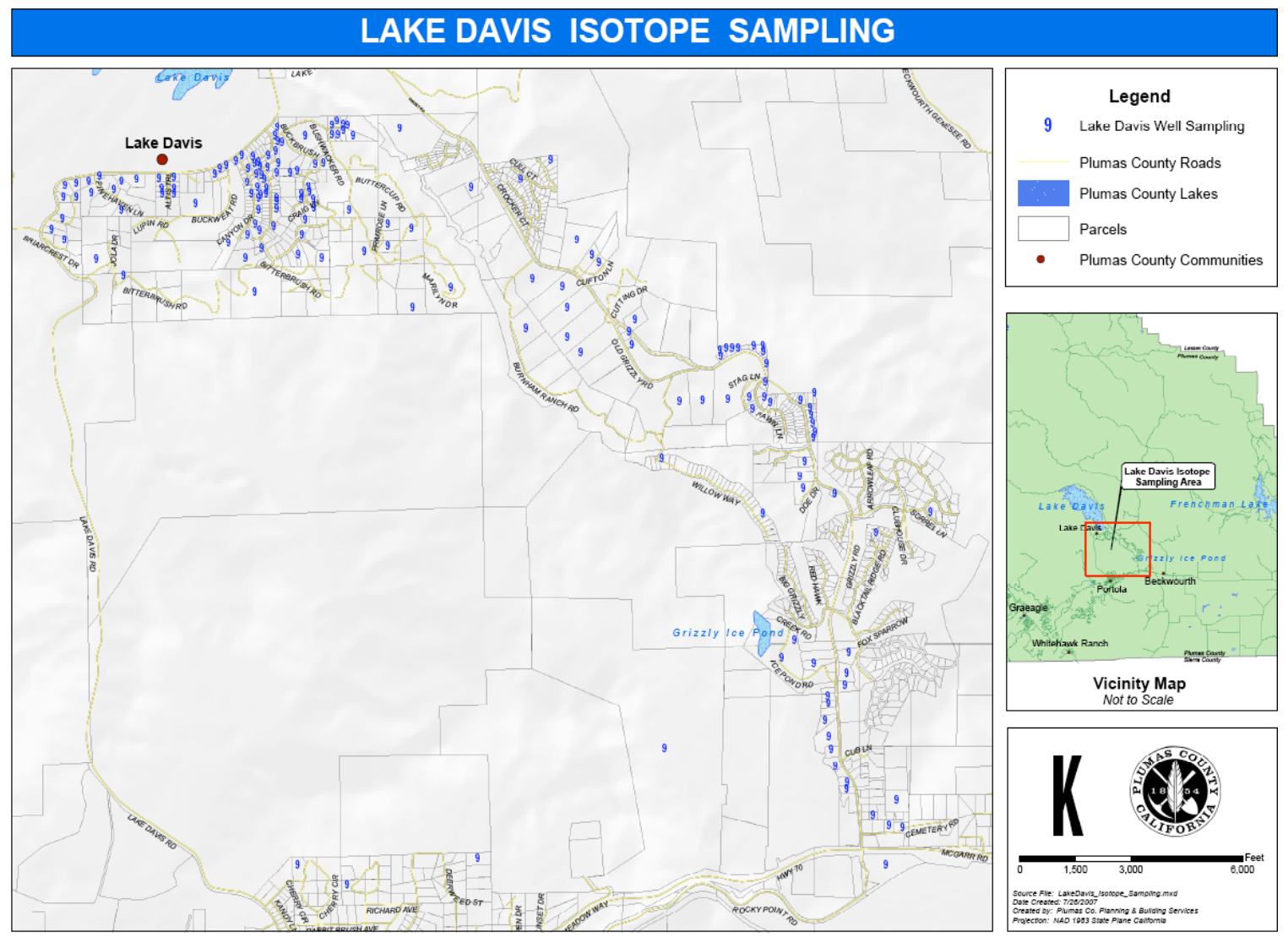

Figure 4. Oxygen Isotope Sampling Locations 


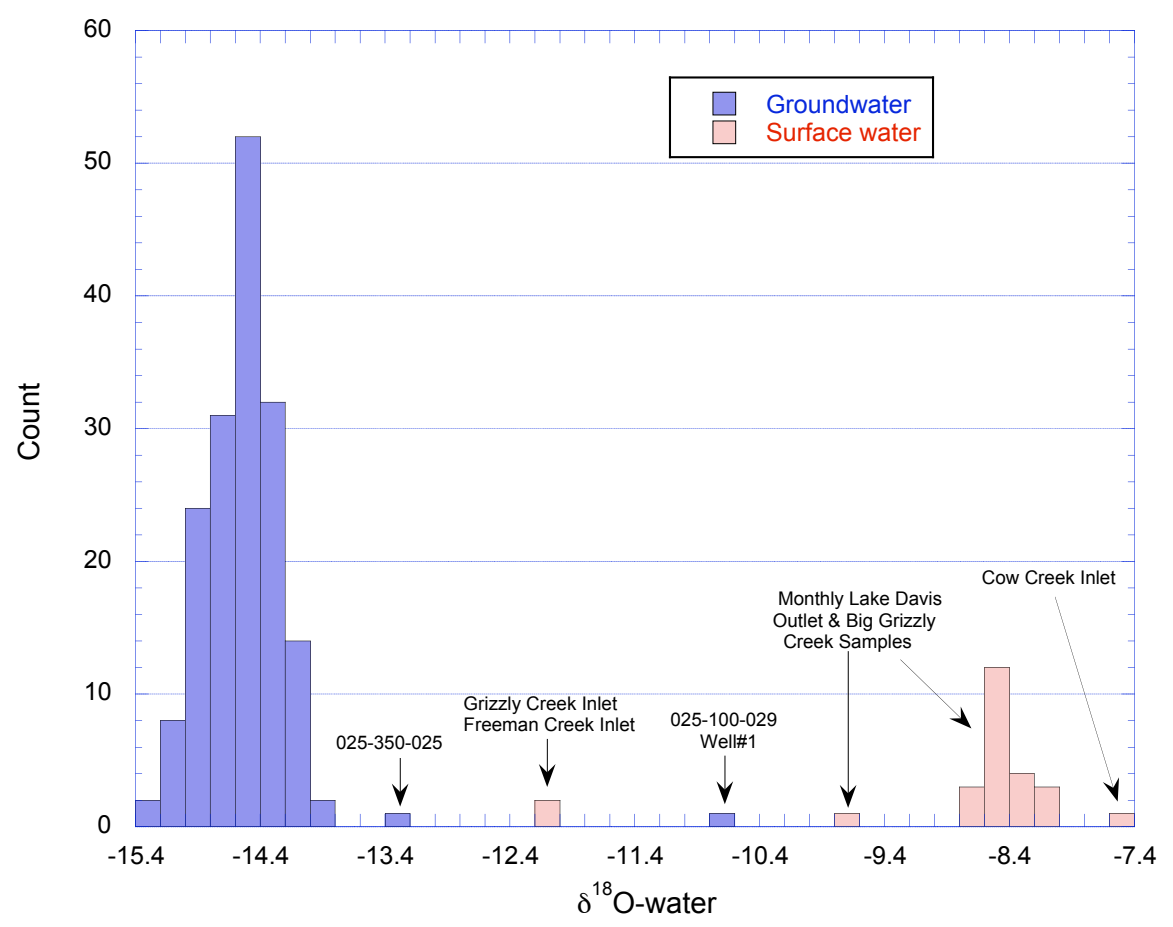

Figure 5. Stable isotope composition of oxygen in waters collected in and around Lake Davis. Groundwater samples have an average $\delta^{18} \mathrm{O}$ value of $-14.6 \% \pm 0.1 \%$. Surface water from Lake Davis has an average $\delta^{18} \mathrm{O}$ value of $-8.6 \%$. Uncertainty for this measurement is $\pm 0.1 \%$. 


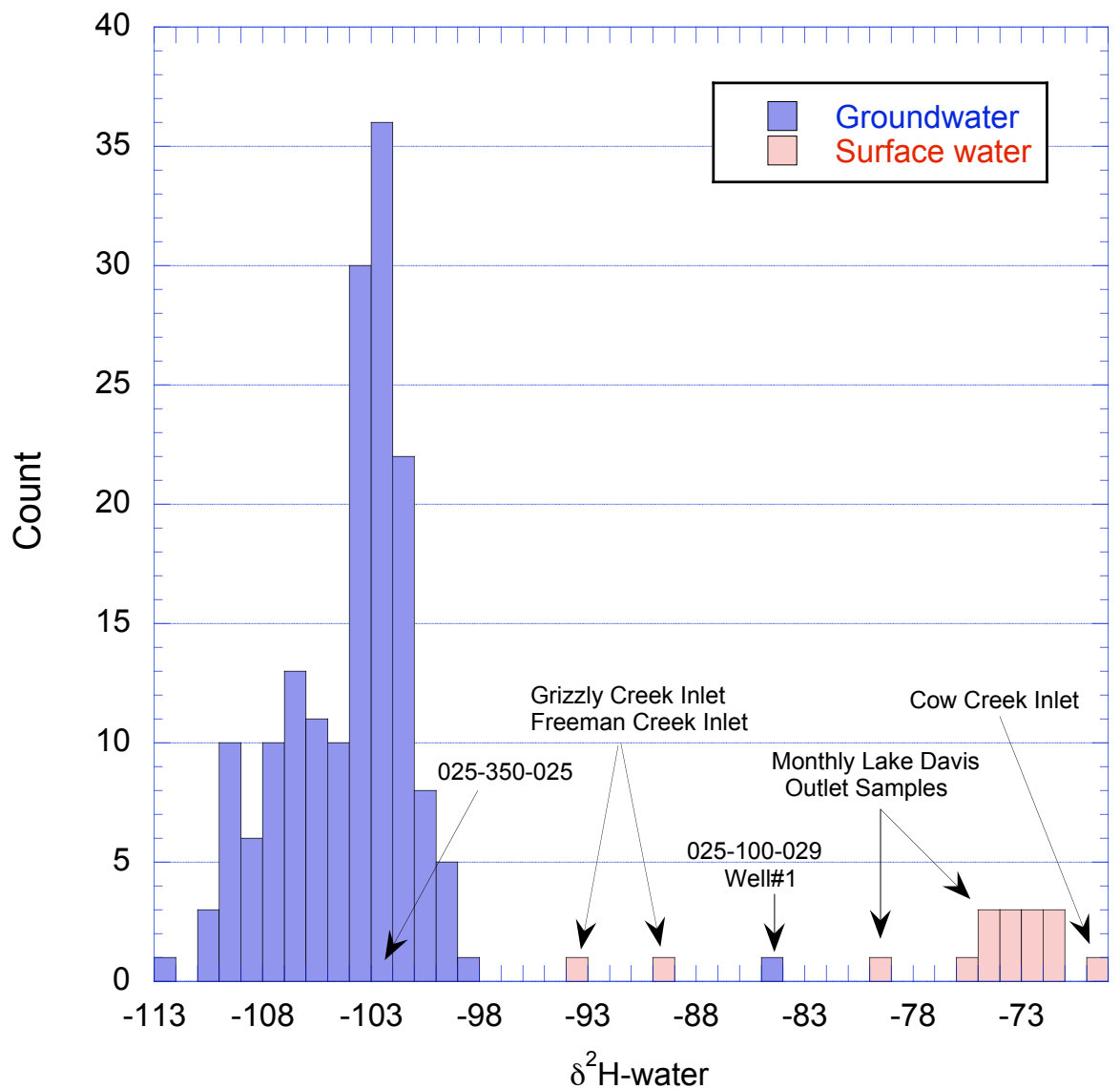

Figure 6. Stable isotope composition of hydrogen in waters collected in and around Lake Davis. Groundwater samples have an average $\delta^{2} \mathrm{H}$ value of $-104 \% \pm \pm 1 \%$. Surface water from Lake Davis has an average $\delta^{2} \mathrm{H}$ value of $-75 \%$. $\pm 1 \%$. 


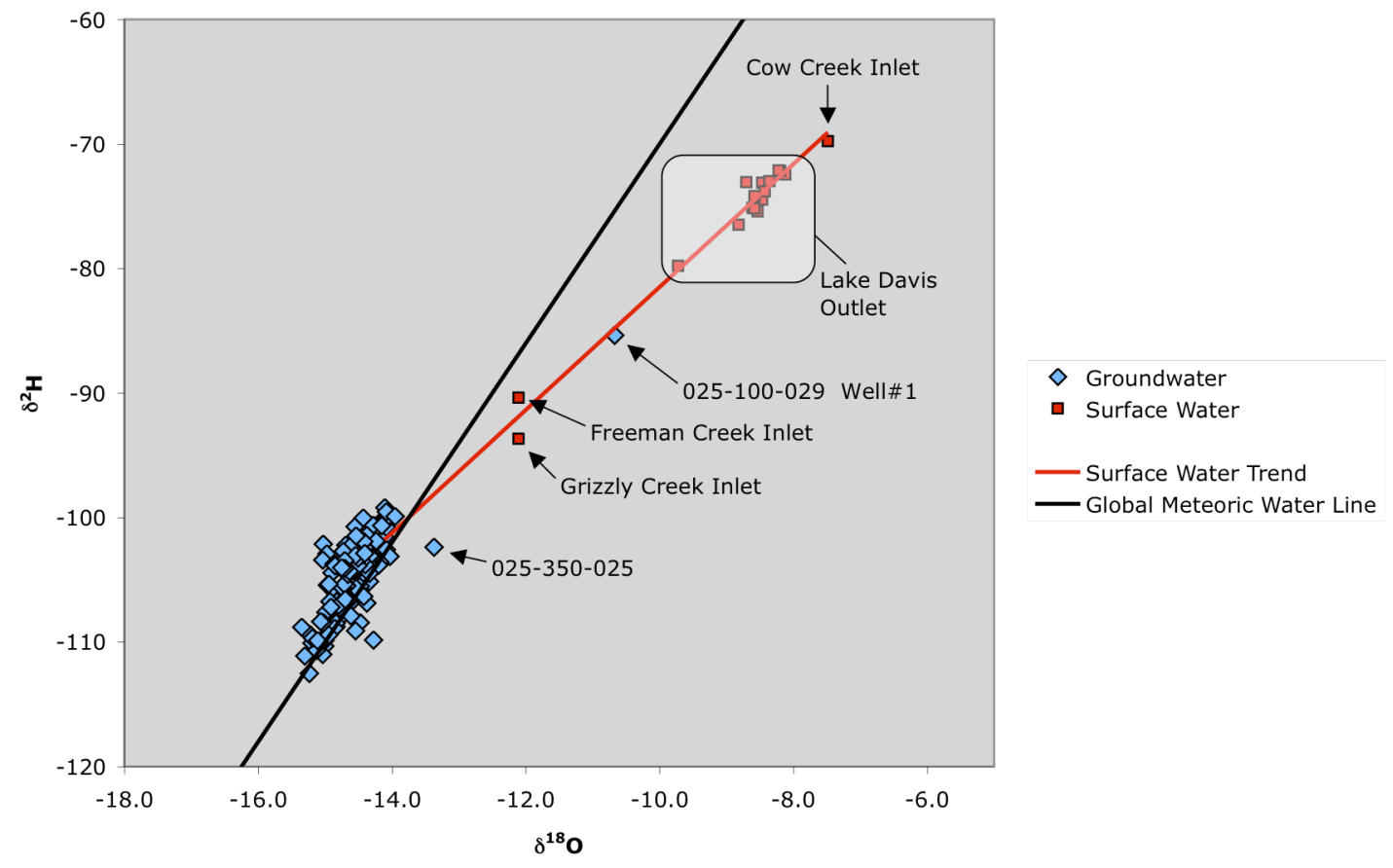

Figure 7. Hydrogen and oxygen isotopic compositions of water collected in and around Lake Davis. 


\section{Tables}


Table 1a. Groundwater Oxygen and Deuterium Results

\begin{tabular}{|c|c|c|c|}
\hline Collection Date & Location Match ID & $\delta^{18} \mathrm{O}$-water & $\delta^{2} H$-water \\
\hline "4/26/2007 & "025-280-005 & -14.5 & $\begin{array}{c}-102 \\
\end{array}$ \\
\hline $5 / 1 / 2007$ & $025-350-029$ & -14.9 & -107 \\
\hline $5 / 1 / 2007$ & $025-350-018$ & -14.7 & -107 \\
\hline $5 / 1 / 2007$ & $025-350-017$ & -14.7 & -107 \\
\hline $5 / 1 / 2007$ & 025-490-001 & -15.0 & -102 \\
\hline $5 / 1 / 2007$ & $025-490-016$ & -14.5 & -108 \\
\hline $5 / 1 / 2007$ & $025-490-015$ & -14.8 & -108 \\
\hline $5 / 1 / 2007$ & $128-060-036$ & -14.1 & -101 \\
\hline $5 / 1 / 2007$ & $128-060-026$ & -14.8 & -109 \\
\hline $5 / 1 / 2007$ & $128-152-008$ & -14.4 & -104 \\
\hline $5 / 1 / 2007$ & $128-152-007$ & -14.4 & -104 \\
\hline $5 / 2 / 2007$ & $128-132-011$ & -14.9 & -108 \\
\hline $5 / 2 / 2007$ & $128-050-010$ & -15.0 & -110 \\
\hline $5 / 2 / 2007$ & $128-030-007$ & -15.0 & -108 \\
\hline $5 / 1 / 2007$ & $025-350-027$ & -14.6 & -105 \\
\hline $5 / 2 / 2007$ & $128-001-027$ & -14.3 & -104 \\
\hline $5 / 2 / 2007$ & $128-010-048$ & -14.6 & -107 \\
\hline $5 / 2 / 2007$ & $128-030-008$ & -15.2 & -110 \\
\hline $5 / 1 / 2007$ & 025-200-011 & -15.0 & -110 \\
\hline $5 / 1 / 2007$ & $128-152-009$ & -14.5 & -102 \\
\hline $5 / 1 / 2007$ & $128-143-001$ & -14.1 & -102 \\
\hline $5 / 1 / 2007$ & $128-131-006$ & -15.0 & -110 \\
\hline $5 / 1 / 2007$ & $128-131-007$ & -14.8 & -108 \\
\hline $5 / 1 / 2007$ & $128-122-001$ & -14.8 & -108 \\
\hline $5 / 1 / 2007$ & $128-110-018$ & -14.3 & -105 \\
\hline $5 / 1 / 2007$ & $128-110-017$ & -14.8 & -107 \\
\hline $5 / 1 / 2007$ & $128-110-006$ & -14.2 & -103 \\
\hline $5 / 1 / 2007$ & $128-110-014$ & -14.5 & -106 \\
\hline $5 / 3 / 2007$ & $025-240-077$ & -14.4 & -103 \\
\hline $5 / 3 / 2007$ & 025-240-078 & -14.5 & -101 \\
\hline $5 / 3 / 2007$ & 025-293-007 & -14.3 & -103 \\
\hline $5 / 3 / 2007$ & 025-293-004 & -14.3 & -102 \\
\hline $5 / 3 / 2007$ & 025-294-004 & -14.3 & -101 \\
\hline $5 / 3 / 2007$ & 025-294-005 & -14.5 & -106 \\
\hline $5 / 3 / 2007$ & 025-251-004 & -14.6 & -104 \\
\hline $5 / 3 / 2007$ & $025-540-007$ & -14.7 & -104 \\
\hline $5 / 3 / 2007$ & 025-500-029 & -14.5 & -105 \\
\hline $5 / 3 / 2007$ & $025-270-031$ & -14.1 & -99 \\
\hline $5 / 3 / 2007$ & $125-051-009$ & -14.1 & -103 \\
\hline $5 / 3 / 2007$ & $025-330-004$ & -14.6 & -107 \\
\hline $5 / 3 / 2007$ & $025-330-003$ & -14.6 & -101 \\
\hline $5 / 3 / 2007$ & 025-511-001 & -15.0 & -105 \\
\hline $5 / 3 / 2007$ & 025-511-002 & -15.0 & -103 \\
\hline $5 / 3 / 2007$ & $025-240-072$ & -14.5 & -102 \\
\hline $5 / 3 / 2007$ & 025-521-003 & -14.6 & -105 \\
\hline $5 / 3 / 2007$ & 025-291-001 & -14.4 & -103 \\
\hline $5 / 3 / 2007$ & 025-292-004 & -14.6 & -104 \\
\hline $5 / 3 / 2007$ & 025-251-001 & -14.6 & -103 \\
\hline
\end{tabular}


Table 1b. Groundwater Oxygen and Deuterium Results Collection Location

\begin{tabular}{|c|c|c|c|}
\hline Date & Match ID & $\delta^{18}$ O-water & $\delta^{2}$ H-water \\
\hline $5 / 3 / 2007$ & $025-240-085$ & -14.6 & -103 \\
\hline $5 / 8 / 2007$ & $125-051-061$ & -14.1 & -101 \\
\hline $5 / 8 / 2007$ & $025-240-093$ & -14.5 & -102 \\
\hline $5 / 8 / 2007$ & 025-240-098 & -14.6 & -103 \\
\hline $5 / 8 / 2007$ & 025-293-008 & -14.4 & -104 \\
\hline $5 / 8 / 2007$ & $025-303-003$ & -14.5 & -106 \\
\hline $5 / 8 / 2007$ & $025-302-005$ & -14.3 & -103 \\
\hline 5/8/2007 & 025-313-005 & -14.7 & -103 \\
\hline $5 / 8 / 2007$ & $025-370-007$ & -14.8 & -107 \\
\hline $5 / 8 / 2007$ & $025-370-040$ & -14.9 & -106 \\
\hline $5 / 8 / 2007$ & $025-260-023$ & -14.5 & -109 \\
\hline $5 / 8 / 2007$ & $025-260-014$ & -14.3 & -102 \\
\hline $5 / 8 / 2007$ & $025-260-013$ & -14.4 & -102 \\
\hline $5 / 8 / 2007$ & $025-540-006$ & -14.5 & -102 \\
\hline $5 / 8 / 2007$ & $025-160-035$ & -14.4 & -107 \\
\hline 5/8/2007 & $025-350-025$ & -13.4 & -102 \\
\hline $5 / 8 / 2007$ & $025-350-021$ & -14.3 & -110 \\
\hline $5 / 8 / 2007$ & 025-350-009 & -15.0 & -111 \\
\hline 5/8/2007 & $025-350-008$ & -15.0 & -110 \\
\hline $5 / 8 / 2007$ & 025-490-021 & -14.8 & -108 \\
\hline $5 / 8 / 2007$ & $128-040-005$ & -15.2 & -113 \\
\hline $5 / 8 / 2007$ & $128-210-013$ & -14.1 & -103 \\
\hline 5/8/2007 & 128-010-012 & -14.7 & -105 \\
\hline \multirow[t]{2}{*}{$5 / 8 / 2007$} & $128-144-001$ & -14.1 & -100 \\
\hline & 025-100-029 & & \\
\hline \multirow[t]{2}{*}{$5 / 9 / 2007$} & Well\#1 & -10.7 & -85 \\
\hline & 025-100-029 & & \\
\hline $5 / 9 / 2007$ & Well\#2 & -14.8 & -106 \\
\hline 5/9/2007 & 025-040-030 & -14.1 & -100 \\
\hline 5/9/2007 & 028-040-030 & -15.0 & -110 \\
\hline $5 / 9 / 2007$ & 028-010-016 & -14.9 & -109 \\
\hline $5 / 9 / 2007$ & $128-060-047$ & -14.0 & -103 \\
\hline $5 / 9 / 2007$ & $128-132-005$ & -15.0 & -108 \\
\hline 5/9/2007 & $128-110-013$ & -14.4 & -104 \\
\hline $5 / 9 / 2007$ & $128-144-005$ & -14.5 & -104 \\
\hline 5/9/2007 & $128-030-009$ & -14.8 & -107 \\
\hline $5 / 9 / 2007$ & $128-010-038$ & -14.5 & -104 \\
\hline 5/9/2007 & $128-010-037$ & -14.4 & -100 \\
\hline $5 / 9 / 2007$ & $128-030-011$ & -14.9 & -106 \\
\hline $5 / 10 / 2007$ & $025-312-005$ & -14.5 & -103 \\
\hline $5 / 10 / 2007$ & $025-302-007$ & -14.5 & -104 \\
\hline $5 / 10 / 2007$ & $025-312-014$ & -14.5 & -103 \\
\hline $5 / 10 / 2007$ & $025-730-010$ & -14.4 & -103 \\
\hline $5 / 10 / 2007$ & 025-303-009 & -14.1 & -100 \\
\hline $5 / 10 / 2007$ & 025-313-004 & -14.9 & -107 \\
\hline $5 / 10 / 2007$ & $025-280-004$ & -14.6 & -104 \\
\hline $5 / 10 / 2007$ & $025-370-030$ & -14.4 & -103 \\
\hline $5 / 10 / 2007$ & $025-370-023$ & -14.8 & -107 \\
\hline
\end{tabular}




\section{Table 2. Surface Water Oxygen and Deuterium Results}

\begin{tabular}{|c|c|c|c|}
\hline $\begin{array}{c}\text { Collection } \\
\text { Date } \\
\end{array}$ & Location Match ID & $\delta^{18} \mathrm{O}$-water & $\delta^{2} \mathrm{H}$-water \\
\hline $9 / 21 / 2006$ & Grizzly Creek Inlet - Lake Davis & -12.1 & -94 \\
\hline $9 / 21 / 2006$ & Freeman Creek Inlet - Lake Davis & -12.1 & -90 \\
\hline $9 / 21 / 2006$ & Jenkins Creek Inlet - Lake Davis & -8.5 & -73 \\
\hline $9 / 21 / 2006$ & Cow Creek Inlet - Lake Davis & -7.5 & -70 \\
\hline $9 / 21 / 2006$ & Below Thermocline - Lake Davis & -8.8 & -76 \\
\hline $9 / 21 / 2006$ & Above Thermocline - Lake Davis & -8.7 & -73 \\
\hline $9 / 21 / 2006$ & Outlet of Lake Davis & -9.7 & -80 \\
\hline $10 / 21 / 2006$ & Outlet of Lake Davis & -8.5 & -74 \\
\hline $11 / 22 / 2006$ & Outlet of Lake Davis & -8.1 & -72 \\
\hline $12 / 21 / 2006$ & Outlet of Lake Davis & -8.2 & -72 \\
\hline $1 / 22 / 2007$ & Outlet of Lake Davis & -8.4 & -73 \\
\hline $2 / 21 / 2007$ & Outlet of Lake Davis & -8.4 & -74 \\
\hline $3 / 21 / 2007$ & Outlet of Lake Davis & -8.5 & -75 \\
\hline $4 / 20 / 2007$ & Outlet of Lake Davis & -8.6 & -75 \\
\hline $5 / 22 / 2007$ & Outlet of Lake Davis & -8.6 & -75 \\
\hline $7 / 21 / 2007$ & Outlet of Lake Davis & -8.6 & -74 \\
\hline $7 / 22 / 2007$ & Outlet of Lake Davis & -8.2 & -72 \\
\hline $8 / 9 / 2007$ & Grizzly Creek \#1 & -8.4 & -71 \\
\hline $8 / 9 / 2007$ & Grizzly Creek \#2 & -8.6 & \\
\hline $8 / 9 / 2007$ & Grizzly Creek \#3 (ice pond) & -8.7 & -74 \\
\hline $8 / 9 / 2007$ & Grizzly Creek \#4 & -8.6 & -74 \\
\hline $8 / 9 / 2007$ & Grizzly Creek \#5 & -8.6 & -73 \\
\hline $8 / 9 / 2007$ & Grizzly Creek \#6 & -8.6 & -70 \\
\hline $8 / 9 / 2007$ & Grizzly Creek \#7 & -8.5 & -71 \\
\hline $8 / 9 / 2007$ & Grizzly Creek \#8a & -8.4 & -73 \\
\hline $8 / 9 / 2007$ & Grizzly Creek \#8b Duplicate & -8.6 & -72 \\
\hline
\end{tabular}


Table 1c. Groundwater Oxygen and Deuterium Results

\begin{tabular}{|c|c|c|c|}
\hline $\begin{array}{c}\text { Collection } \\
\text { Date }\end{array}$ & $\begin{array}{c}\text { Location } \\
\text { Match ID } \\
\end{array}$ & $\delta^{18} \mathrm{O}$-water & $\delta^{2}$ H-water \\
\hline $5 / 10 / 2007$ & $025-500-007$ & -14.7 & -106 \\
\hline $5 / 10 / 2007$ & $025-500-022$ & -14.2 & -104 \\
\hline $5 / 15 / 2007$ & $125-460-015$ & -14.2 & -104 \\
\hline $5 / 15 / 2007$ & $025-240-082$ & -14.6 & -103 \\
\hline $5 / 15 / 2007$ & $025-511-007$ & -14.6 & -103 \\
\hline $5 / 15 / 2007$ & $025-312-008$ & -14.5 & -106 \\
\hline $5 / 15 / 2007$ & $025-303-015$ & -14.9 & -107 \\
\hline $5 / 15 / 2007$ & $025-313-002$ & -14.5 & -106 \\
\hline $5 / 15 / 2007$ & 025-270-019 & -14.3 & -103 \\
\hline $5 / 15 / 2007$ & $025-240-034$ & -14.3 & -104 \\
\hline $5 / 15 / 2007$ & $128-050-017$ & -15.1 & -111 \\
\hline $5 / 15 / 2007$ & $128-110-011$ & -14.3 & -104 \\
\hline $5 / 15 / 2007$ & 025-490-017 & -14.4 & -106 \\
\hline $5 / 15 / 2007$ & $025-160-036$ & -14.6 & -108 \\
\hline $5 / 16 / 2007$ & 025-330-002 & -14.5 & -103 \\
\hline $5 / 16 / 2007$ & 025-303-007 & -14.6 & -104 \\
\hline $5 / 16 / 2007$ & $025-500-012$ & -14.4 & -101 \\
\hline $5 / 16 / 2007$ & $025-370-036$ & -14.7 & -105 \\
\hline $5 / 16 / 2007$ & $028-370-003$ & -15.0 & -103 \\
\hline $5 / 16 / 2007$ & 025-341-001 & -14.3 & -103 \\
\hline $5 / 16 / 2007$ & $128-040-002$ & -14.4 & -104 \\
\hline $5 / 16 / 2007$ & $128-050-018$ & -15.2 & -109 \\
\hline $5 / 16 / 2007$ & $128-160-011$ & -15.1 & -110 \\
\hline $5 / 16 / 2007$ & $128-110-016$ & -14.7 & -106 \\
\hline $5 / 16 / 2007$ & $128-110-001$ & -14.7 & -105 \\
\hline $5 / 17 / 2007$ & $025-330-005$ & -14.5 & -102 \\
\hline $5 / 17 / 2007$ & 025-240-095 & -14.7 & -103 \\
\hline $5 / 17 / 2007$ & $025-511-006$ & -14.7 & -104 \\
\hline $5 / 17 / 2007$ & $025-511-008$ & -14.7 & -103 \\
\hline $5 / 17 / 2007$ & 025-303-001 & -14.6 & -103 \\
\hline $5 / 17 / 2007$ & $025-370-011$ & -14.5 & -103 \\
\hline $5 / 17 / 2007$ & $025-500-030$ & -14.6 & -103 \\
\hline $5 / 17 / 2007$ & $025-500-027$ & -14.7 & -104 \\
\hline $5 / 17 / 2007$ & $025-500-026$ & -14.5 & -104 \\
\hline $5 / 17 / 2007$ & $128-110-015$ & -14.5 & -103 \\
\hline $5 / 22 / 2007$ & 025-293-006 & -14.2 & -101 \\
\hline $5 / 22 / 2007$ & 025-293-016 & -14.6 & -104 \\
\hline $5 / 22 / 2007$ & $025-270-017$ & -14.5 & -104 \\
\hline $5 / 22 / 2007$ & $025-521-005$ & -14.4 & -103 \\
\hline $5 / 27 / 2007$ & $025-240-050$ & -14.7 & -102 \\
\hline $5 / 27 / 2007$ & $025-292-007$ & -14.5 & -102 \\
\hline $5 / 27 / 2007$ & $025-323-004$ & -14.9 & -104 \\
\hline $5 / 27 / 2007$ & $025-500-017$ & -14.5 & -103 \\
\hline $5 / 27 / 2007$ & $025-500-008$ & -14.7 & -105 \\
\hline $5 / 27 / 2007$ & $025-270-006$ & -14.4 & -102 \\
\hline $5 / 27 / 2007$ & $025-270-035$ & -14.4 & -103 \\
\hline $5 / 27 / 2007$ & $025-341-002$ & -14.5 & -102 \\
\hline $5 / 27 / 2007$ & $025-341-006$ & -14.5 & -102 \\
\hline
\end{tabular}


Table 1d. Groundwater Oxygen and Deuterium Results Collection

\begin{tabular}{cccc} 
Date & Location Match ID & $\delta^{\mathbf{1 8}}$ O-water & $\delta^{2}$ H-water \\
\hline \hline $5 / 27 / 2007$ & $025-341-005$ & -14.6 & -102 \\
$5 / 27 / 2007$ & $025-341-004$ & -14.6 & -102 \\
$5 / 29 / 2007$ & $025-540-004$ & -14.7 & -103 \\
$5 / 29 / 2007$ & $025-270-014$ & -14.2 & -102 \\
$5 / 29 / 2007$ & $025-293-011$ & -14.0 & -100 \\
$5 / 29 / 2007$ & $025-303-013$ & -14.6 & -103 \\
$5 / 29 / 2007$ & $025-500-025$ & -14.9 & -104 \\
$5 / 31 / 2007$ & $128-060-040$ & -15.1 & -108 \\
$5 / 31 / 2007$ & $028-060-014$ & -15.3 & -111 \\
$5 / 31 / 2007$ & $025-370-033$ & -14.4 & -102 \\
& & & \\
& U.S.F.S. & & \\
$5 / 31 / 2007$ & Grasshopper/Grizzly & -14.7 & -107 \\
$5 / 31 / 2007$ & $025-270-024$ & -14.6 & -104 \\
& U.S.F.S. & & \\
$5 / 31 / 2007$ & Campground & & \\
$7 / 9 / 2007$ & Lightning Tree & -14.9 & -109 \\
$7 / 10 / 2007$ & $025-511-005$ & -14.8 & -104 \\
$7 / 11 / 2007$ & $128-190-003$ & -15.4 & -109 \\
$7 / 12 / 2007$ & $128-190-006$ & -15.2 & -110 \\
$7 / 13 / 2007$ & $128-072-003$ & -14.7 & -103 \\
$7 / 14 / 2007$ & $025-511-004$ & -14.7 & -104 \\
$7 / 15 / 2007$ & $025-240-102$ & -14.4 & -102 \\
$7 / 16 / 2007$ & $025-240-065$ & -14.9 & -104 \\
$7 / 17 / 2007$ & $025-240-013$ & -14.5 & -101 \\
$7 / 18 / 2007$ & $025-200-011$ & -15.1 & -110 \\
$7 / 19 / 2007$ & $025-240-033$ & -14.9 & -105 \\
$7 / 20 / 2007$ & $025-304-009$ & -14.8 & -104 \\
\hline & $025-292-011$ & -14.4 & -103 \\
\hline
\end{tabular}




\begin{tabular}{|c|c|c|c|}
\hline Parcel Number & Parcel Number & Parcel Number & Parcel Number \\
\hline $025-100-029$ & 025-293-009 & $025-370-036$ & $128-030-007$ \\
\hline $025-100-032$ & 025-293-011 & $025-370-040$ & $128-030-008$ \\
\hline $025-100-032$ & $025-293-016$ & $025-490-015$ & $128-030-009$ \\
\hline $025-160-018$ & 025-294-006 & $025-490-016$ & $128-030-011$ \\
\hline $025-160-035$ & $025-302-006$ & 025-490-017 & $128-030-022$ \\
\hline $025-160-036$ & $025-302-007$ & 025-490-021 & $128-030-088$ \\
\hline $025-200-011$ & 025-303-001 & $025-500-007$ & $128-040-002$ \\
\hline $025-200-011$ & 025-303-007 & $025-500-008$ & $128-040-005$ \\
\hline $025-240-013$ & 025-303-009 & $025-500-012$ & $128-050-017$ \\
\hline $025-240-033$ & $025-303-013$ & $025-500-017$ & $128-050-018$ \\
\hline $025-240-034$ & $025-303-015$ & $025-500-022$ & $128-050-020$ \\
\hline $025-240-050$ & $025-303-015$ & $025-500-025$ & $128-060-026$ \\
\hline $025-240-065$ & 025-304-009 & $025-500-026$ & $128-060-040$ \\
\hline $025-240-077$ & $025-312-005$ & $025-500-027$ & $128-072-003$ \\
\hline $025-240-082$ & $025-312-008$ & $025-500-029$ & $128-092-006$ \\
\hline $025-240-085$ & $025-312-014$ & $025-500-030$ & $128-110-001$ \\
\hline $025-240-090$ & 025-313-002 & $025-511-001$ & $128-110-006$ \\
\hline $025-240-093$ & 025-313-004 & 025-511-002 & $128-110-011$ \\
\hline $025-240-095$ & 025-313-005 & $025-511-004$ & $128-110-013$ \\
\hline $025-240-098$ & 025-323-004 & $025-511-005$ & $128-110-014$ \\
\hline $025-240-102$ & 025-330-002 & $025-511-006$ & $128-110-015$ \\
\hline $025-260-013$ & $025-330-003$ & $025-511-007$ & $128-110-016$ \\
\hline $025-260-014$ & 025-330-004 & 025-511-008 & $128-110-017$ \\
\hline $025-260-022$ & 025-330-005 & $025-521-001$ & $128-110-018$ \\
\hline $025-260-023$ & $025-341-001$ & $025-521-003$ & $128-122-001$ \\
\hline $025-270-006$ & $025-341-002$ & $025-521-005$ & $128-131-006$ \\
\hline $025-270-014$ & $025-341-004$ & 025-540-004 & $128-132-001$ \\
\hline $025-270-017$ & $025-341-005$ & 025-540-006 & $128-132-005$ \\
\hline 025-270-019 & $025-341-006$ & $025-540-007$ & $128-141-001$ \\
\hline $025-270-024$ & $025-350-008$ & $025-730-010$ & $128-143-001$ \\
\hline $025-270-031$ & 025-350-009 & 028-010-016 & $128-144-001$ \\
\hline $025-270-035$ & $025-350-017$ & 028-030-010 & $128-144-005$ \\
\hline $025-280-004$ & $025-350-018$ & 028-040-030 & $128-152-007$ \\
\hline $025-280-005$ & $025-350-021$ & 028-060-014 & $128-152-008$ \\
\hline $025-282-004$ & $025-350-025$ & 028-293-008 & $128-152-009$ \\
\hline 025-291-001 & $025-350-027$ & $028-370-003$ & $128-160-011$ \\
\hline $025-292-007$ & $025-350-029$ & $125-051-009$ & $128-190-003$ \\
\hline 025-292-011 & $025-370-007$ & $125-460-015$ & $128-190-006$ \\
\hline 025-293-001 & $025-370-011$ & $128-010-012$ & $\begin{array}{l}\text { 128-210-013 } \\
\text { Grasshopper }\end{array}$ \\
\hline 025-293-004 & $025-370-023$ & $128-010-037$ & $\begin{array}{l}\text { Campground } \\
\text { Lighting Tree }\end{array}$ \\
\hline 025-293-006 & $025-370-030$ & $128-010-038$ & Campground \\
\hline 025-293-007 & $025-370-033$ & $128-010-048$ & \\
\hline
\end{tabular}




\section{Appendices}




\section{Appendix A. Analytical Method-Stable Isotopes}

Oxygen isotope analyses are conducted using the carbon dioxide equilibration method for ${ }^{18} \mathrm{O} / 16 \mathrm{O}$ (Epstein \& Mayeda, 1953) and analyzed with an automated water equilibration unit. Isotope ratio measurements are performed on a VG PRISM isotope ratio mass spectrometer housed in the Chemical Sciences Division at Lawrence Livermore National Laboratory. Oxygen isotope ratios are reported in the standard delta $(\delta)$ notation as parts per thousand (per mil or \%) variations relative to a reference material of known composition and defined by the following equation:

$$
\delta_{x}=1000 \frac{R_{x}-R_{\text {std }}}{R_{\text {std }}}
$$

where $R_{x}$ is the ${ }^{18}$ Oxygen/16 Oygen $\left({ }^{18} \mathrm{O} /{ }^{16} \mathrm{O}\right)$ ratio of the sample. The conventional standard reference material for oxygen isotopes is Standard Mean Ocean Water (SMOW; Craig, 1961). Analyses in the Stable Isotope Laboratory are calibrated to internal standards referenced against National Institute of Standards and Technology (NIST) standard reference materials. Internal standards consist of (1) Pacific Ocean water sample $\delta^{18} \mathrm{O}=+0.35 \%$ ), (2) two isotopically distinct California meteoric water samples $\delta^{18} \mathrm{O}=-9.78$ and $-14.62 \%$ ), and (3) Alaskan Tap Water (-21.02\%). The composition and isotopic values of these internal standards span the range of natural waters typically observed in potable groundwater of California. For each $24 \delta^{18} \mathrm{O}$ analyses, 2 each of 3 internal standards are also analyzed and used for calibration.

The internal standards are periodically compared to the three NIST reference standards: SMOW, Standard Light Antarctic Precipitation (SLAP), and Greenland Ice Sheet Precipitation (GISP). The analytical precision for these $\delta_{18} \mathrm{O}$ measurements, from one run to the next, is $\pm 0.10 \%$, which is defined in terms of the difference of the internal standard from the precisely known NIST standards. One duplicate is analyzed for every eighteen samples. These duplicates are not "blind" however, but are typically samples from the previous run. If this duplicate varies by more than $\pm 0.10 \%$, the sample is run for a third time. If this duplicate is not with the $0.10 \%$ precision, the entire set of eighteen samples is re-analyzed.

To detect Lake Davis water in a groundwater well, approximately $15 \%$ of the source water needs to be from Lake Davis or from Big Grizzly Creek. 


\section{Appendix B. Isotope Sampling Procedure}

1. Locate sampling port closest to well head

2. Turn on water

3. Wait for initial pressure switch engagement of submersible pump (This is visually confirmed by increased flow of water).

4. Collect grab sample

5. Perform and record Water Quality parameters that include $\mathrm{pH}$, dissolved oxygen, temperature and specific conductance

6. Continue collecting grab samples and record Water Quality parameters until stabilization occurs. ( $\mathrm{pH}$ is within $0.1 \mathrm{pH}$ unit, temperature is within $0.5 \mathrm{C}$ and specific conductance is within plus or minus $3 \%$.)

7. Use $30 \mathrm{ml}$ glass bottle (clear, French -square type) with Qorpak T polyseal-lined cap

8. Triple rinse with water directly from sampling port

9. Fill just below threads, re-apply cap and tighten firmly

10. Dry off sample bottle, label accordingly, to include APN, physical address, current time and date

11. Record sample information on "chain of custody," form

12. Pack to assure safety from breakage, no preservation or refrigeration is required.

\section{References}

Craig, H. (1961), Standard for reporting concentrations of deuterium and oxygen-18 in natural waters," Science 133, 1833-1834.

Epstein, S., and T. K. Mayeda (1953), "Variation of $18 \mathrm{O}$ content of waters from natural sources," Geochimica et Cosmochimica Acta 4, 213-224.

Leland R. Gardner and Associates (1999). Reevaluation of the Hydrogeology of the Lake Davis - Portola Region. Palo Alto, California.

Ridley, M. (2006). Review and assessment of Plumas County's groundwater quality monitoring at Lake Davis. Lawrence Livermore National Laboratory, Livermore, California. 
